DOI https://doi.org/10.24195/spj1561-1264.2020.4.14

\author{
Okorokova Vira Viktorivna \\ Doctor of Philosophical Sciences, \\ Associate Professor at the Department of the World History and Methodology of Science \\ South Ukrainian National Pedagogical University named after K. D. Ushynsky \\ 26 Staroportofrankovskaya str., Odesa, Ukraine \\ ORCID ID: 0000-0003-0661-4313
}

\title{
HISTORIOSOPHICAL FUNDAMENTALS OF SIMULYACRUM IN THE ROUTE OF THE POSTMODERNISTIC PARADIGM
}

The article is devoted to the study of the phenomenon of simulacra in the course of historiosophical analysis. The relevance and scientific novelty of this issue is determined by the socio-cultural transformation of modern society. The latter is expressed in the process of virtualization of society as a result of simulation of social reality. The simulacrum in this case is the basis of cognition/construction of the social environment, at the subconscious level forms a social model, the scope of which is a virtual environment.

The methodological basis of the scientific article includes the use of methods specific to the philosophy of history. It is a dialectical method that made it possible to study the simulacrum within the historical genesis of society, the peculiarities of its worldview. Also a transcendental method, which allowed us to consider the category of simulacra at the epistemological level.

The article notes that the simulacrum is a form of knowledge of the world around us, inherent in man. From ancient times we can see its manifestations on the example of the expression of creative activity, especially in, for example, artistic creativity. With the development and improvement of the scientific and technical sphere, simulacra as signs - copies - have found their embodiment in cyberspace, the virtual world. The search for pleasure, the realization of those properties that man has not been able to reveal in historical reality, produces a simulation world that offers a new virtual world created on the basis of reality.

At the ontological level, simulacra become a motive and an element of activity that reproduce the unreal, embody signs in the artificial world, the virtual world. The latter indicates their peculiar temporal characteristic, which speaks of temporality in a certain space. The outlined understanding of simulacra allows the author to emphasize that the postmodern worldview is a conceptual basis in the study of simulacra. The latter in postmodern historiosophy are images - models of a new social reality, representative forms of which are the media, the Internet, social networks, and finally virtual reality as such.

Key words: virtualization of society, virtual reality, postmodernism, simulacrum.

Introduction. In modern social reality, the process of materialization of time is increasingly observed. On the one hand, man is in the grip of time, which controls all life processes. On the other hand, she is again trying to put time into the cycle. That is, we are talking about the fact that the space in which modern man is, is differentiated into real and modeled. Everything combines and generates the same consequences, the real meaning disappears, it is replaced by monotonous models designed to give people a guarantee of uniformity and invisibility of their daily existence. In this regard, S. Urazova notes but the deep problem of interaction between media and society was and remains the question of the formation of meanings associated with the content of historical time, clothed in popular media forms [12, p. 417]. The latter are a product of the iconic culture of the information society. That is, we are talking about a simulacrum.

The simulation concept in modern historiosophy occupies a special place. Especially when it comes to studying the simulacrum within the postmodernist paradigm. This is largely due to the fact that the simulacrum is a product of postmodernism, within which the iconic culture is of great importance. Nowadays, we see how a separate type of reality is formed on the basis of simulacrum signs virtual, which is based on simulation, i. e. the replacement of reality as such. Such modern scientists 
as R. Hnatyuk, P. Grechko, O. Danilyan, V. Yemelin, V. Kaftan, E. Kurmeleva, O. Novikova, S. Urazova, studying the simulacrum in the vein of postmodernism, virtualization of society, distinguish its nature, features, importance in the process of virtualization of society.

For example, V. Emelin speaking about virtual reality defines it as an organized space of simulacra - special objects, "alienated signs", which, in contrast to the copy signs, fix not the similarity, but the difference with the reference reality. In contrast to the actual reality, expressing integrity, stability and completeness, virtual reality is a source of difference and diversity. Thus, virtuality is a phenomenon immanent in the very structure of being, embodying the possibility of creative, generating activity [6].

Other researchers, O. Danilyan and O. Dzoban, note that the reality of the simulacrum masks not the absence of true reality, but of any reality in general. The simulacrum presupposes the existence of some true (illusory) world [4].

R. Hnatyuk and M. Kolinko generally talk about the processes of simularization, which penetrate into all spheres of public life and have a strong influence on the social structure, thereby setting a new basis for material and spiritual values [2, p. 21].

Thus, the aim of the article is a historiosophical analysis of the simulacrum within the postmodernist paradigm.

Research methods. The methodological basis of the article includes the use of the following methods: dialectical (provided an opportunity to explain the simulacrum in the historical genesis of worldview), transcendental (enabled the disclosure of the simulacrum through the prism of its formation, expression, which works especially well in modern society in its virtualization).

Results and discussion. It is known that the conceptualization of the simulation concept occurred in the studies of J. Deleuze and J. Baudrillard, who define a simulacrum as a sign that acquires its own being, creates its own reality, and, in fact, brings the very idea of a sign to the point of absurdity, to elimination. It is not even a "centaur of sign and body". In fact, the simulacrum itself is a body, but a virtual body, i.e. it is just as real as any body that is a referent is real, but it is real virtually. That is why a simulacrum is not a sign in the full sense of the concept of a sign, but it itself can be a reference in relation to the next-order simulacrum representing it. The simulacrum begins where the likeness ends. It is there that virtual reality begins, which is nothing but the space of simulacra [6].

So, J. Baudriyard called postmodernism the era of total simulation. In the situation of the postmodern suspension, if the reality is transformed into a model, the contrast between the action and signs is erased, everything is transformed into a simulacrum - a copy, as if the image is imagined, but in reality it is not a little original At the thought of a philosopher, the very meaning of reality, say: well, what can be equivalently seen. The same value is determined at once from science, so I postulate that any process can be accurately reproduced in the given minds, and in the promiscuous rational, that postulates a universal system of equivalence (the class is the representative of the transcendental. As a result of the creative process, reality appears - not just those that can be created, but those that have already been introduced into the hyperreality [1, p. 151]. For, for the firmness of J. Deliose, the food is about those who are real, concrete, or explicit, inconsistently delivered. Difference pass not between the clear and the real, but also go like this and with the trivial camp of speeches, such as her challenges and in which you won't go [5].

Simulacra are the only reality available to us. There is simply no other reality, no other world for us (our feelings and our consciousness). This world becomes simulative or just imaginary for us. The space of the imaginary is the method of constitution that underlies what is commonly called modern social reality. This applies equally to the processes of distortion of reality. Reality signs replace reality, become hyperreality, in which the perception of reality is based not on facts, but on simulations. In connection with the increasing role of the Internet as a means of mass communication, the speed of exchange of simulative constructions is increasing [8, p. 54].

Examining the historical roots of the simulacrum, E. Kurmeleva notes that the simulacrum in the conceptual sense we inherited from Greek culture. Plato's "Simulacrum" is a copy of a copy, and its ontological status is very low. A simulacrum is not a reflection of an original idea, but just a reflection 
of a reflection, it copies a thing, which itself is a copy (with one degree or another) of an idea, of eternal and absolute being. The sphere of manifestation of simulacra is, first of all, the sphere of art. They do not deceive, deliberately mislead or create a new reality. Simulacra are artificial images in which the artist reflects what he sees around him. The theory of simulacra is closely related to the theory of mimesis (imitation), which lies at the heart of ancient Greek ideas about art [9, p. 31].

In the epoch of modern times another meaning is assigned to the concept of "simulacrum". A simulacrum is no longer so much a copy of a copy, an image two steps away from the original, but nevertheless testifying to it, as an illusion, a trick. Simulate - to create appearances, deceive, pretend and even deliberately distort reality. To a large extent, this interpretation was due to a departure from the theory of mimesis, that is, to the refusal to consider art only as an imitation of reality. Nevertheless, the simulacrum continues to be included in a certain common (single) reality for everything and for all.

Since about the end of the 20th century, the term "simulacrum" has become the key for postmodern thinking. In postmodern theories, the interpretation of the concept of "simulacrum" has changed radically, which is associated with the crisis of the theory of representation. The latter is the basis of both the theory of reflection and the theory of mimesis, and, more broadly, the classical approach to language (as a particular system of signs) and the reality that it represents. This theory is based on the principle of correspondence (equivalence) between consciousness and reality, between a copy and an original, between a concept and a thing, between a sign and a referent, etc. A copy does not exist just like that, there is always a sample that it reproduces. If you remove the original (sample), its copy will also disappear. A sign always refers to its referent, indicates a certain reality, of which it is a sign. The value of a sign is not in itself, but precisely in this reality contained in it or standing behind it [9, p. 32].

P. Grechko, considering the history of the emergence of simulacra in Western culture, notes that the individual, the individual has always been considered limited in their affairs and thoughts and therefore can only simulate the existential fullness of the original. The situation was mitigated, but not saved, again consistently changing each other's reasoning that man is a microcosm that embodies the macrocosm, that he is the image and likeness of God, that individual cogito open horizons of the transcendental and therefore universal subproject. Obviously, a microcosm could be equal to a macrocosm only if it were preformist demiurgic. But such an ability and strength in the microcosm in the great cosmocentric world was not [3, p. 29].

Remarkable in this case is the three-level scheme of existence of simulacra in history, proposed by J. Baudrillard in the work "Symbolic exchange and death". Namely, the scientist proposes a scheme of three levels that replace each other in European civilization from the Renaissance to the present day: forgery - production - simulation. The first-order simulacrum operates on the basis of the natural law of value, the second-order simulacrum - on the basis of the market law of value, the third-order simulacrum - on the basis of the structural law of value. Because simulacra, which are heterogeneous in material, show profound structural and stage similarities, their development does not take place as a gradual and uneven transition, but as a general structural revolution.

At the first stage the sign reflects certain states, at the second - hides a certain situation and passes into the realm of ideology, at the third stage the sign hides the absence of reality, at the last stage the sign begins to exist as an independent whole. Each configuration of the sign is reinterpreted following it and falls into a higher category of simulacra. In the system of each such new stage the integrated system of the previous phase is revealed - as a ghostly, simulated correlation. Each new order of simulacra is subordinate to the previous one.

In this three-member scheme, we can see the asymmetry associated with the heterogeneity of objects that become "samples" for simulacra: if counterfeiting (e. g., imitation of expensive materials) and production (production of serial industrial goods) relate to material things, the simulation is applied faster to processes (simulation of actions, activities) or signs, symbols (simulation of disease, etc.). There is also a zero level of simulation - the level of technology, solutions, independent of the system of signs, symbols or real objects [11, p. 34]. 
According to J. Baudrillard, the last form of simulation is regulated by code. Code is the main category of structuralists and semiotics, which allows to organize and reduce to spatial forms the "crazy" existence of temporal forms. Thus, J. Baudrillard considers the history of society as a process of population of social reality by erroneous objects, and assumes the role of the exposer of this erroneous reality. To such a worldview basis, the French thinker reduces the simulation project, which interprets the history of society as a system of changing the state of the simulacrum from "true" to "false" [1, p. 35].

In Baudrillard's understanding, the modern world has lost reality, replacing it with hyperreality. A sign as a symbol of identification and self-reflection becomes a simulacrum passing through 4 stages of its development. At the first stage, a reflection of a certain deep reality occurs, the second stage is represented by the masking and perversion of this reality, the third presupposes the masking of the absence of any deep reality, and the fourth is the loss of any connection with reality, that is, the conversion of the sign into a simulacrum. Postmodern thinkers define simulacrum as a sign that acquires its own being and, in essence, ceases to be a sign. The simulacrum is itself a body, but a virtual body [10, p. 23].

In contrast to actual reality, which expresses integrity, stability and completeness, virtual reality is a source of difference and diversity (or the illusion of such). Simulacra as virtual objects have always been present in various guises in individual and social life and have even been an effective means of influencing the course of history. The desire to create alternative worlds without prejudice to the real world in the computer field materialized for so long. With regard to the computer, virtual reality is inextricably linked with graphic technologies, which, through the feedback-endowed human-computer interaction, give the effect of being in some other, different from the real, artificial world [7, p. 90].

Entering cyberspace, a person begins to feel himself not just surrounded by some strange landscapes, unreal bodies, but he himself becomes such a body - a simulacrum, a "de-materialized" body. This fact is already beyond the scope of events of a purely technological plan, and such a breakthrough in the field of information activity carries quite significant consequences, both for the individual and for society [7, p. 91].

V. Kaftan and L. Ryazanova denote a fundamental difference between virtual reality and simulative: the first is reproduced exclusively with the help of technical means, is an online space, the second can exist both in online and offline dimensions. It may happen, Baudrillard wrote, that it is no longer the bodies that will cast their shadows, but the shadows that will cast their bodies, which will become only the shadow of a shadow. This is already happening in the case of virtual reality, which is just a re-introduced abstraction and digital life. Simulated reality is a more general concept in relation to virtual reality. Online and offline measurements are simulative in nature, however, technical means are a condition for the existence of virtual reality. The phenomena of simulative and virtual realities are neutral in nature, which means that the authors fundamentally reject the identification of simulative reality with purposefully constructed constructions that have a negative interpretation. They are characterized as environments in which a manipulative component may or may not be present $[8$, p. 55].

Conclusions. The simulation of social reality is considered as a specific characteristic of the postmodern onto-gnoseological perception of the world. Virtual technologies are essentially a product of simulacra, which cannot be called a new phenomenon. Historiosophical analysis shows that they have existed since the era of the ancient world. The only difference here is that simulacra, depending on the technological level, have different forms of expression. The point is that, in fact, simulacra at the psychological level are inherent in human consciousness, act as a reaction to the perception of the surrounding world. In our time, virtual information technology is just one of the possible embodiments of simulation, the manifestations of which we can find in different spheres of life.

\section{BIBLIOGRAPHY}

1. Бодрийяр Ж. Символический обмен и смерть. Москва : Добросвет, 2000. 387 с.

2. Гнатюк Р.Г., Колинько М.В. Симулятивная реальность в эпоху постмодерна. Вісник студентського наукового товариства Донецького національного університету імені Василя Cmyca. 2013. T. 1. № 5. C. 21-27. 
3. Гречко П.К. Постмодерный конструкционизм. Вопросы соџиальной теории. 2013-2014. T. VII. Вып. 112. С. 25-42.

4. Данильян О.Г., Дзьобань О.П. «Симулякр»: концептуалізація феномена у постнекласичній філософії. Інформація і право. 2016. № 2(17). С. 66-76.

5. Делез Ж. Платон и симулякр. Новое литературное обозрение. 1993. № 5. С. 45-56.

6. Емелин В.А. Виртуальная реальность и симулякры. URL: http://emeline.narod.ru/virtual.htm.

7. Емелин В.А. Симулякры и технологии виртуализации в информационном обществе. Наџиональный психологический журнал. 2016. № 3(23). С. 86-97.

8. Кафтан В.В., Рязанова Л.В. Концепции виртуальной и симулятивной реальности в условиях цифровой трансформации. Власть. 2019. № 3. С. 53-56.

9. Курмелева Е.М., Мещерякова Л.Ю. Симулякр и общество в современной социальной теории. Вестник Российского университета дружбы народов. Серия «Сочиология». 2006. № 2. C. 31-47. URL: https://cyberleninka.ru/article/n/simulyakr-i-obschestvo-v-sovremennoysotsialnoy-teorii/viewer.

10. Новикова О.Н. Виртуальный игровой мир как симулякр жизни. Гуманитарный вектор. 2017. T. 12. № 3. C. 23-29.

11. Окорокова В.В. Образ нової соціальної реальності Постмодерну та форми його моделювання : монографія. Одеса : ВМВ, 2018. 288 с.

12. Уразова С.Л., Кильпеляйнен Е.С. Виртуальная реальность и медиареальность: тенденции и прогнозы эволюции медиасистемы. Вестник Российского университета дружбь народов. Серия «Литературоведение. Журналистика». 2018. Т. 23. № 4. С. 410-421.

\section{REFERENCES}

1. Bodriyyar, Zh. (2000). Simvolicheskiy obmen i smert' [Symbolic exchange and death]. Moscow: Dobrosvet [in Russian].

2. Gnatyuk, R.G., Kolin'ko, M.V. (2013). Simulyativnaya real'nost' v epokhu postmoderna [Simulated reality in the postmodern era]. Visnyk studentskoho naukovoho tovarystva Donetskoho natsionalnoho universytetu imeni Vasylia Stusa - Bulletin of the Student Scientific Society of Vasyl Stus Donetsk National University, vol. 1, no. 5, pp. 21-27 [in Russian].

3. Grechko, P.K. (2013-2014). Postmodernyy konstruktsionizm [Postmodern constructionism]. Voprosy sotsial'noy teorii - Social theory issues, vol. VII, iss. 112, pp. 25-42 [in Russian].

4. Danylian, O.H., Dzoban, O.P. (2016). "Symuliakr": kontseptualizatsiia fenomena u postneklasychnii filosofii ["Simulacrum": conceptualization of the phenomenon in post-classical philosophy]. Informatsiia i pravo - Information and law, no. 2917), pp. 66-76 [in Ukrainian].

5. Delez, Zh. (1993). Platon i simulyakr [Plato and the simulacrum]. Novoe literaturnoe obozrenieNew literary review, no. 5, pp. 45-56 [in Russian].

6. Emelin, V.A. (1999). Virtual'naya real'nost' i simulyakry [Virtual reality and simulacra]. Retrieved from: http://emeline.narod.ru/virtual.htm [in Russian].

7. Emelin, V.A. (2016). Simulyakry i tekhnologii virtualizatsii v informatsionnom obshchestve [Simulacra and virtualization technologies in the information society]. Natsional 'nyy psikhologicheskiy zhurnal - National Psychological Journal, no. 3(23), pp. 86-97 [in Russian].

8. Kaftan, V.V., Ryazanova, L.V. (2019). Kontseptsii virtual'noy i simulyativnoy real'nosti v usloviyakh tsifrovoy transformatsii [Virtual and simulated reality concepts in digital transformation]. Vlast'- Power, no. 3, pp. 53-56 [in Russian].

9. Kurmeleva, E.M., Meshcheryakova, L.Yu. (2006). Simulyakr i obshchestvo v sovremennoy sotsial'noy teorii [Simulacrum and society in modern social theory]. Vestnik Rossiyskogo universiteta druzhby narodov. Seriya "Sotsiologiya" - Bulletin of the Peoples' Friendship University of Russia. Series "Sociology", no. 2, pp. 31-47. Retrieved from: https://cyberleninka.ru/article/n/simulyakr-iobschestvo-v-sovremennoy-sotsialnoy-teorii/viewer [in Russian].

10. Novikova, O.N. (2017). Virtual'nyy igrovoy mir kak simulyakr zhizni [The virtual game world is like a simulacrum of life]. Gumanitarnyy vector - Humanitarian vector, vol. 12, no. 3, pp. 23-29 [in Russian].

11. Okorokova, V.V. (2018). Obraz novoi sotsialnoi realnosti Postmodernu ta formy yoho modeliuvannia: monohrafiia [The image of the new social reality of Postmodernism and forms of its modeling: a monograph]. Odesa: VMV [in Ukrainian]. 
12. Urazova, S.L., Kil'pelyaynen, E.S. (2018). Virtual'naya real'nost' i mediareal'nost': tendentsii i prognozy evolyutsii mediasistemy [Virtual reality and media reality: trends and forecasts of the evolution of the media system]. Vestnik Rossiyskogo universiteta druzhby narodov. Seriya "Literaturovedenie. Zhurnalistika" - Bulletin of the Peoples'Friendship University of Russia. Series "Literary Criticism. Journalism”, vol. 23, no. 4, pp. 410-421 [in Russian].

\section{Окорокова Віра Вікторівна}

доктор філософських наук, доцент кафедри всесвітньої історії та методології науки Південноукраїнського національного педагогічного університету імені К. Д. Ушинського вул. Старопортофранківська 26, Одеса, Україна

ORCID ID: 0000-0003-0661-4313

\section{ІСТОРІОСОФСЬКІ ЗАСАДИ СИМУЛЯКРУ В РУСЛІ ПОСТМОДЕРНІСТСЬКОЇ ПАРАДИГМИ}

Статтю присвячено дослідженню явища симулякру в руслі історіософського аналізу. Актуальність $i$ наукова новизна иієї проблематики визначаються соціокультурною трансформацією сучасного суспільства. Останнє виражається у прочесі віртуалізації суспільства як результату симулящіі соціальної реальності. Симулякр у иъьому випадку $\epsilon$ основою пізнання/конструювання соиіального середовища, на підсвідомому рівні формує соиіальну модель, сферою реалізації якої є віртуальне середовище.

Методологічний базис статті включає використання методів, притаманних саме філософії історії. Ідеться про діалектичний метод, який дав змогу дослідити симулякр y межах історичного генезису суспільства, особливостей його світосприйняття; про трансиендентальний метод, який дав можливість розглянути категорію симулякру на гносеологічному рівні.

У статті зазначається, щзо симулякр є формою пізнання оточуючого світу, притаманною невід'ємно людині. 3 давніх часів ми можемо побачити його прояви на прикладі творчої діяльності, особливо ие стосується, наприклад, художньої творчості. Із часом у процесі розвитку ци удосконалення науково-технічної сфери симулякри як знаки-копії знайшли своє втілення в кіберпросторі, віртуальному світі. Пошуки задоволення, реалізація тих властивостей, якілюдинане змогларозкрити в історичній дійсності, продукують симулячійний світ, який пропонує новий віртуальний світ, створений на основі реальності.

На онтологічному рівні симулякри стають мотивом та елементом діяльності, які відтворюють ірреальне, утілюють знаки у штучний світ, віртуальний світ. Останнє вказує на їх своєрідну темпоральну характеристику, яка свідчить про тимчасовість у визначеному просторі. Окреслене розуміння симулякру дає авторові змогу наголошувати на тому, щзо постмодерністське світосприйняття є концептуальною основою в дослідженні симулякрів. Останні в постмодерністській історіософії єобразами-моделями нової соиіальноїреальності, репрезентативними формами якої є засоби мас-медіа, інтернет, сочіальні мережі, а також віртуальна реальність як така.

Ключові слова: віртуалізація суспільства, віртуальна реальність, постмодернізм, симулякр. 